\title{
The role of gender on the effects of Indonesian manpower skills on their competition readiness/preparedness
}

\author{
Setyabudi Indartono \\ Nahiyah Jaidi F. \\ Yogyakarta State University, Indonesia
}

\section{Keywords}

Worker, skill, competition readiness

\begin{abstract}
The Asean economic community requires high economic competition among ASEAN countries. Indonesia is one of the ASEAN Countries which is assumed to have a low capacity to win the competition. Hence, Indonesian workers are sued to have a better skill level heading the tight competition. Thus, workers with better skills are needed to strengthen the comptetition. Both practition and scholars believe that the issues of gender are currently attractive for the manpower market. Accordingly, this study is aimed to explore the effects of gender on the influence of skill on the readiness of Indonesia worker toward business competition in the Asean Economic Community (AEC). This study employs 352 workers from various Industries. Multiple regressions are used to analyze the data. The result shows that the skill of male workers has stronger effect on their readiness toward AEC competition rather than their counterparts. Implication and future research are discussed.
\end{abstract}

\section{Introduction}

The issues of free flow of skilled labor has important implications for economic and productivity growth among countries of Asean Economic Community/AEC (Fumarco \& Rossi, 2018; Blix, 2018; Allen, Burgess, \& Mayo,2018; Kraisuth \& Panjakajornsak, 2018; Gitaharie \& Soelistianingsih, 2018; Nambiar, 2018; Malik, Lenka, \&Sahoo, 2018). AEC has an ambitious vision. It is an agreement of free flow of goods, services,investments and skilled labor, and freer flow of capital to enhance the transformation of this regional association of states into a single market and production based, a highly competitive economic region, a region of equitable economic development, and a region fully integrated into the global economy (Rana, 2017; Svetlicinii, 2017). The AEC provides for market access for ASEAN professionals and skilled manpower, and promote regional mobility and mutual recognition of professional credentials, and talents and skills development. There aretwo types of manpower flows, i.e; unskilled and semi-skilled workers flowon shortterm contracts, and professionals and skilled manpower flow. However, the AEC covers only the second type of flows.ASEAN countries can be divided into 3 main groups with respect to the mobility ofprofessionals and skilled manpower. The first group is, where inflows of skills far exceeded outflows ofskills (that is, net brain gain). Singapore, Brunei and, to a lesser extent, Thailand are in this category. The second group, where outflows of skills far exceeded inflows of skills (that is, net braindrain). Philippines and Malaysia are in this category.The third group, in the other ASEAN countries i.e., Indonesia and Vietnam, skilled and professional manpower flows are not figure prominently. In these countries, inflows have been limited by restrictive regulations, while outflows have not been significant because of the small pool of professional and skilled manpower and their in adequate English proficiency that restricts their international mobility. Myanmar has English language proficiency but outflows are restricted by the political regime (Yue, 2011).

ASEAN will require more related tutelage and professional training for young women and men to turn into a provincial manufacturing center driven by skills, innovation, and ingenuity (Malik, Lenka, \&Sahoo, 2018). However, the heterogeneity of the workforce is crucial to apply human capital management to model manpower readiness. This heterogeneity is reflected in the different knowledge, skills, abilities'level and attitudes of the workforce (Ngin, 2005). Manpower readiness level is needed to measure the estimation of the final result of competition. It is a concept in which a single scale is applied to an entire system of AEC. Scholars indicate that motivation, needs, emotions, and reflection 
are related to the issues of readiness (Babushkina, Shumilinb, \& Chikurovb, 2011). It is needed to be a precompetition preparation to strengthen the degree they perceive them-selves to be ready in facing their competitors (LeMaire, Short, Ross-Stewart, \& Short, 2007). Lack of readiness in providing skilled workers is argued to be the factors that contribute to the readiness issue in AEC. Workers are likely to avoid the competitive situations where they did not believe chances were good that they would win (Firmin, Lucius, \& Johnson, 2011).The Asean economic community promotes the open opportunities to the ASEAN countriesto fight each others in order to integrate their resources. The AEC as a liberal system is believed to promote the rescaling of economic governance, involving regulatory changes that may radically redistribute power and resources. ThusAEC countries try to promote various programs in term of strengthening and protecting their interests (Soesastro, 2003; LooiKee, Nicita, \&Olarreaga, 2009; Arellano-Yanguas, \&Bernal-Gómez, 2017; Nair, 2018; Siadari\& Arai, 2018).

Governments regulate various roles to protect their service sectors within the liberalization world. Indonesia and Malaysia are found as countries with highest restrictiveness index (Llanto, Medalla, Del Prado, Mantaring, Detros, Serafica, Ortiz, Kristina, Ortiz, Padronia, \& Maddawin, 2015; Nur, Hadiwardoyo, Nahry, \& Nahdalina, 2017; Su, Sun, Lei, Weng, \& Cai, 2017). The Indonesian government has also identified modernization, standards and conformance, and developed their infrastructure to deal with the key challenges in the implementation of the AEC (Soesastro, 2008). That in turn, it shows that AEC countries try to update their implementation status of the standard and conformance to support their competitive industries and quality consciousness in the production of goods and services. Thus countries try totake advantages of the AEC regulations by accelerating the skills of their workforces (Llanto et al., 2015). It is indicated that Indonesian low-level qualified workers separate in various positions with lower education levels and have limited access to up-skilling or re-skilling opportunities.

Kis-Katos,Pieters, \& Sparrow (2017) found that female labour force participation has been remarkably stagnant around 50 per cent over the last 25 years. The global and regional trade integration intensify, understanding its impact on gender inequalities in the labour market. Labour market impacts can be gender specific for a number of reasons i.e.: increasing the demand for female workers relative to male workers, female workers can increase on reducing the physical strength required for manual work, and male and female workers are imperfect substitutes. There are various issues of female workers in Indonesia. Indonesian women are three times more likely than men to be engaged in unpaid, women have relatively low education and wealth, and female labourforce participation is increasing in urban areas. They from poor regions and families, have low education level and social status, and lack of professional work skills seem to put a challenging work abroad as migrant workers (Sukesi, Setyowati, Wahyuningtyas, \& Baladina, 2018). This phenomenon able to changes their socio-economic, cultural behavior, and forms of transnational families (Sukesietal., 2018; Winarnita, 2018). Accordingly, it is plausibel to explore the different effect of gender on the readiness of Indonesian workforce to deal with global AEC challenges of competitions.

\section{Manpowers' Skill on the AEC Competition}

AEC requires highly knowledge and skill mobility among countries member. It is included challenges and opportunities such as portable qualifications, increased access to the skilled labor market, adequate supply of skilled professionals, and strong demand for skilled professionals. The challenge ASEAN States face is threefold. First, the complexity of the qualifications recognition process essentially discourages professionals who move within the region from having their professional and academic credentials assessed and recognized. Second, professionals face restricted access to the ASEAN labor market due to nationallevel barriers such as constitutional provisions reserving particular occupations for nationals, and complex and opaque requirements and procedures for employment visas. Finally, many professionals themselves have limited interest in moving within the region due to perceived cultural, language, and socio economic differences (Papademetriou, Sugiyarto, Mendoza \& Salant, 2016).

According to the United Nations' most recent estimates, 70\% of the 9.5 million migrants in the ASEAN region in 2013 (or 6.5 million people) were from other ASEAN States. About $97 \%$ of the 6.5 million intra-ASEAN migrants in 2013 circulated between just three countries: Thailand, Malaysia, and Singapore. One million migrants each from Indonesia, Malaysia, and Lao People's Democratic Republic 
have migrated to Malaysia, Singapore, and Thailand, respectively. The Philippines is also one of the largest sources of temporary labor migrants in the world, but the majority of its foreign workers go to the Middle East, particularly to the Gulf States, since countries in this region have opened their borders to all workers, regardless of skill level. Thailand have nearly all migrants $(97 \%)$ are from other ASEAN countries, but only $3 \%$ of these workers are considered to be highly skilled. The majority of Malaysians' skilled and professional workers come from beyond the ASEAN regions, only $10 \%$ are working in highskilled occupations. AEC allows tourism occupations will be granted automatic recognition as they move within the region while professionals in engineering, nursing, architecture, medicine, and dentistry are eligible after completing compensatory qualifications standards and working practices between the origin and destination country. Accordingly scholars suggest that recognizing qualifications from differences countries should be concern to what a professional must know to practice his or her profession, grant automatic recognition for each occupation across each of the signatory countries, recognition of a school diploma is not the same as recognition of qualifications or the right to practice in regulated occupations, and developed labor-intensive policy (Papademetriou, Sugiyarto, Mendoza, \& Salant, 2016).

\section{Indonesian Manpower Quality}

Manpower mobility among AEC countries is likely to increase within the dynamic changes of trade policy in each countries. The issues of temporarily workers among ASEAN countries which allows professional of a firm located in certain ASEAN country, increase the ASEAN Government attantion to control the effect of AEC agreements effects. Accordingly they change the labor regulations to afford the mutual recognition of professional qualifications, allowing the employee to work without re-qualifying in every national jurisdiction based on their own interests (Jones, 2015). Scholars found various content of regulation within ASEAN countries. Thailand paid their local doctors better to deal with the competition from immigrants, whereas Malaysia, Philippines, Singapore and Thailand free their workers' flow on architectural services (Jones, 2015; Sumano, 2013). The study of quality of Indonesian manpower is found vary. There are more than 30 million secondary education graduates and more than 10 million tertiary education graduates in Indonesia's labor force. Different groups of workers, particularly youth, women and rural dwellers, havehad disparate labor market outcomes, highlighting problems posed by labor market segmentation. Under-qualified workers still separate in various positions. There are a large proportion of those with lower education levels and have limited access to up-skilling or re-skilling opportunities. Further demand for workers with quality vocational and technical skills outstrips supply. Most of them are employed on short-term contracts and/or earning an income that is below the minimum wage. McKinsey estimated that demand for semi-skilled and skilled workers may rise to 113 million by 2030, which is likely to see skills shortages and skills mismatches worsen throughout the economy (Hunt, Layton, \& Prince, 2015)

Based on Vuong, Napier, Vu, Nguyen, \& Tran (2014) competition readiness is ability to observe and forecast threats/risks as well as estimate future costs and benefits of pursuing innovation. It requires various skills and knowledge to generate those processes and requirements. Whereas Blumenstein \& Orbach $(\underline{2016})$ believed that to achieve the international level recognitions, one may have sufficient supports of personality characteristics, knowledge, and skills. The skills are related to people communication, relationship, leadership, and experience in psychological preparation. The knowledge is included theory and methodology of competition areas, technical and tactical preparations, and in managing and organizing their tasks and it's competition. Hence this study proposes that the skills of workers are significantly effect on their readiness of AEC competition.

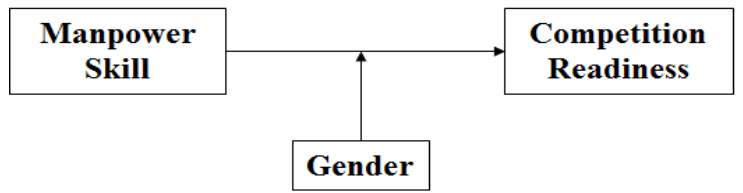

Figure 1. Research model 


\section{Method}

This study employs 352 workers from various industriesin Indonesia. It is included $40.1 \%$ male workers, and they are 29.24 years old averages. Participant are employed from various Industries (table $1)$.

Table 1 Cluster Industries of respondents

\begin{tabular}{ll}
\hline Industries & Percentage \\
\hline Agriculture & 28,98 \\
Mining & 0,85 \\
Processing industry & 7,10 \\
Electricity, Gaz, and clean water & 40,06 \\
Construction & 3,69 \\
Trade, hotel \& restourant & 0,57 \\
Transportation and communication & 15,91 \\
Finance, rental\& service & 0,28 \\
Others & 2,56 \\
\end{tabular}

The instruments used are developed based on forum group discussion from university, HRD of industries, and representative of Ministry of Manpower of the Republic of Indonesia. The samples questions are "I am master at the management and leadership skills" and "I am ready to compete within the AEC labor competition". A 5-point rating scale was used to evaluate skill and knowledge. A higher score indicated that respondent represent high skill competencies. A 10-point rating scale was used to evaluate competition readiness. A higher score indicated that respondent have fully ready to compete toward the competition at Asean Economic community (AEC).

\section{Measure validation}

The Confirmatory factor analysis (CFA) is adopted to test for the quality and adequacy of the measurement model. In accordance with the two-step procedure suggested by Anderson and Gerbing (1988), confirmatory factor analysis (CFA) is performed to examine reliability, convergent and discriminant validity of the multi-item construct measures. Initial specification search led to deletion of some of the items in the constructs scale in order to provide acceptable fit. Selected statistics for the final overall-model assessment show acceptable fit of the measurement model.

Table 2Loading Factor of Constructs

\begin{tabular}{|c|c|c|c|}
\hline Items & & Skill & Readiness \\
\hline $\begin{array}{l}\text { I understand the consequence of Asean Economic community } \\
\text { competition }\end{array}$ & CR1 & & 0,829 \\
\hline $\begin{array}{l}\text { I am ready to compete toward the competition at Asean } \\
\text { Economic community }\end{array}$ & CR2 & & 0,879 \\
\hline My Skill communication & S1 & 0,548 & \\
\hline My conflict managerial skill & S2 & 0,739 & \\
\hline My leadership skill & S3 & 0,727 & \\
\hline My change management skill & S4 & 0,738 & \\
\hline My skill of reading, writing, and hearing & S5 & 0,594 & \\
\hline My presentation skill & S6 & 0,714 & \\
\hline My information technology skill & S7 & 0,634 & \\
\hline My marketing skill & S8 & 0,569 & \\
\hline My English & S9 & 0,582 & \\
\hline
\end{tabular}




\begin{tabular}{|c|c|c|c|}
\hline Items & & Skill & Readiness \\
\hline My foreign language & S10 & & \\
\hline My interpersonal skill & S11 & 0,668 & \\
\hline My emotional quotient & $\mathrm{S} 12$ & 0,650 & \\
\hline My flexibility & S13 & 0,650 & \\
\hline My career management & S14 & 0,806 & \\
\hline My mindful leadership & S15 & 0,829 & \\
\hline My networking skill & S16 & 0,786 & \\
\hline My execution skill & S17 & 0,771 & \\
\hline My entrepreneurship skill & S18 & 0,750 & \\
\hline My innovation skill & S19 & 0,719 & \\
\hline My creativity & S20 & 0,708 & \\
\hline My social literacy & S21 & 0,817 & \\
\hline My cross cultural skill & S22 & 0,772 & \\
\hline My adversity skill & $\mathrm{S} 23$ & 0,686 & \\
\hline My mentoring skill & S24 & 0,793 & \\
\hline My skill of accelerated learning techniques & S25 & 0,749 & \\
\hline My comprehensive thinking & S26 & 0,722 & \\
\hline
\end{tabular}

\section{$\mathrm{S}=\mathrm{Skill} ; \mathrm{CR}=$ Competition Readiness}

Table 1 shows the analysis of loading factor. It is found that 25 from 26 items are valid to measure skill, and 2 valid items are represented the readiness questionnaire. There an item of skill isrejected. Validity tests included convergent and divergent validity. The result of the convergent validity test is accepted. It's assessed by checking individual item loadings for each corresponding research constructing Table 3. It is found that the values of factor loadings are above the recommended value of 0.5. Further Average Variance Constructed (AVE) values are found higher than 0.5 for Competition Readiness and Knowledge. Hence based on Fornell\&Larcker (1981), the convergent validity is accepted.

Table 3 Means, Standard Deviation, $\square$ Value, Loading Factor, Average Variance Extracted

\begin{tabular}{|c|c|c|c|c|c|c|}
\hline & \multirow{3}{*}{ Mean } & \multirow{3}{*}{ SD } & Item-total & a Value & Loading & AVE \\
\hline & & & $\begin{array}{l}\text { Dunn, Seaker and } \\
\text { Waller } 1994\end{array}$ & $\begin{array}{l}\text { Churchill, 1979; Bagozzi and } \\
\text { Yi, 1988; Nunnally and } \\
\text { Bernstein, 1994 }\end{array}$ & $\begin{array}{l}\text { Anderson } \\
\text { and } \\
\text { Gerbing } \\
1988\end{array}$ & $\begin{array}{l}\text { Anderson } \\
\text { and } \\
\text { Gerbing } \\
(1988)\end{array}$ \\
\hline & & & $>.3$ & $>.7$ & $>.35$ & $>.5$ \\
\hline R1 & \multirow{2}{*}{4,805} & \multirow{2}{*}{2,107} & 0,932 & \multirow{2}{*}{0,964} & 0,829 & \multirow{2}{*}{0,730} \\
\hline $\mathrm{R} 2$ & & & 0,932 & & 0,879 & \\
\hline S1 & \multirow{9}{*}{2,824} & \multirow{9}{*}{0,439} & 0,549 & \multirow{9}{*}{0,963} & 0,548 & \multirow{9}{*}{0,508} \\
\hline S2 & & & 0,740 & & 0,739 & \\
\hline S3 & & & 0,727 & & 0,727 & \\
\hline S4 & & & 0,735 & & 0,738 & \\
\hline S5 & & & 0,610 & & 0,594 & \\
\hline S6 & & & 0,716 & & 0,714 & \\
\hline S7 & & & 0,633 & & 0,634 & \\
\hline S8 & & & 0,564 & & 0,569 & \\
\hline S9 & & & 0,591 & & 0,582 & \\
\hline
\end{tabular}




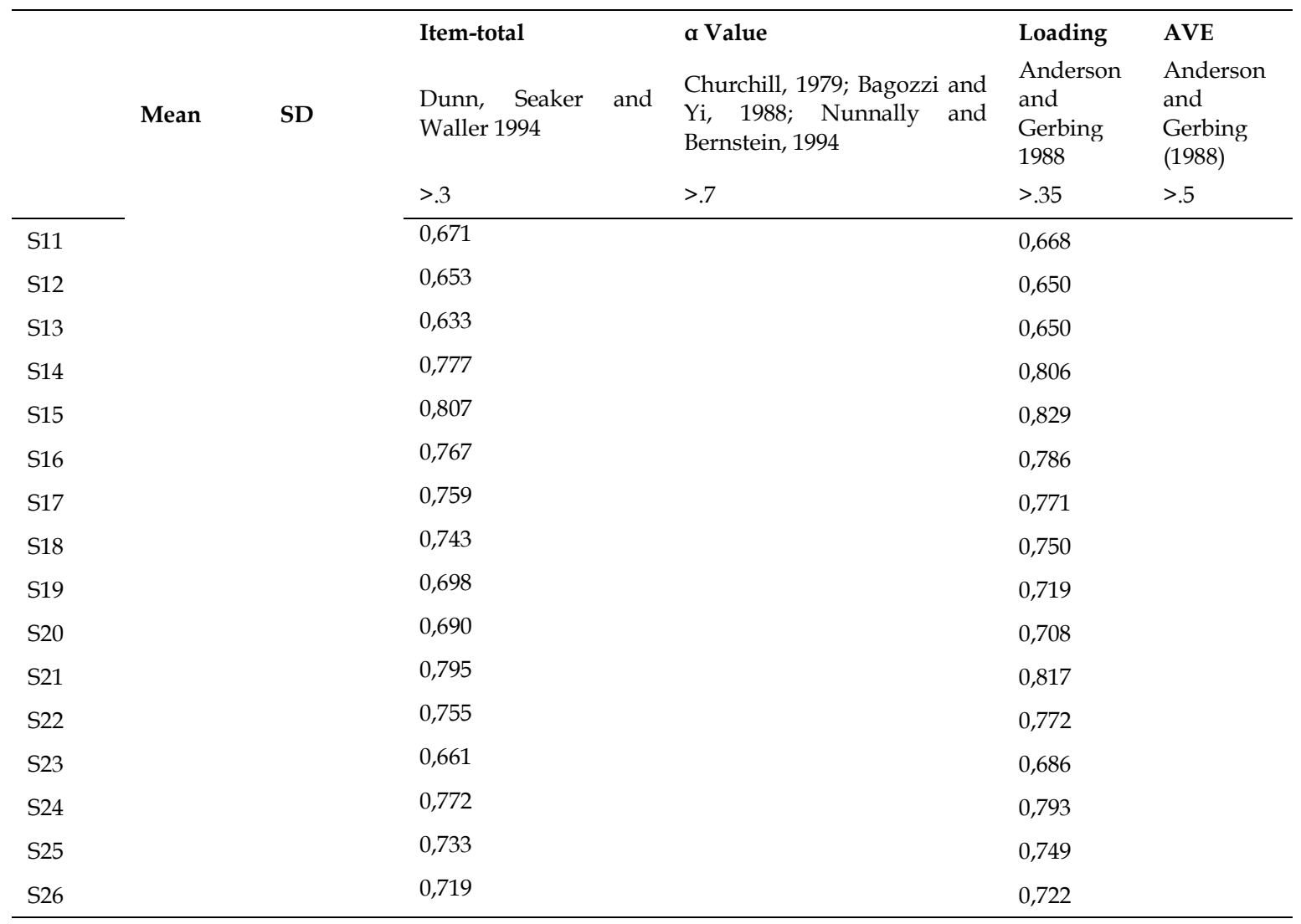

Discriminant validity is indicated by correlation between variables and the values of the square root of AVE. Table 4 shows that the inter-correlation values for all paired latent variables are less than 1,0.Accordingly the values of between variables do not overlap.

Table 4Correlation and Cronbach

\begin{tabular}{lllllll}
\hline & & 1 & 2 & 3 & 4 & 5 \\
\hline 1 & Cluster & - & & & & \\
2 & Ages &, $183^{*+}$ & - & & & \\
3 & Gender &, 007 &,- 085 & - & & \\
4 & Readiness &,- 014 &, 050 &,- 093 & $\mathbf{0 , 9 6 4}$ & \\
5 & Skill &, $111^{*}$ &,$- 135^{*}$ &, 025 &, $172^{+*}$ & $\mathbf{0 , 9 6 3}$ \\
\hline
\end{tabular}

*. Correlation is significant at the 0.05 level (2-tailed).

**. Correlation is significant at the 0.01 level (2-tailed).

\section{Results and Discussion}

This study test the effect of gender on the influence of skill on comptition readines by using multiple regression analysis. Five step of regressions are plays on the overal findings (table 5). At the begining, control variables are regressed on competition readiness. Thus, gender is included on the model to find out the contribution on the competition readiness. Skill are regress with the control variable to affect competition readiness. Finally interaction of skill and gender is regressed to find out the effect on competition readiness.

Table 5The Effect of Male and Female on the Effect of Indonesian Skill Manpower on their Competition Readiness

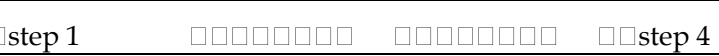$$
\square \square \text { step } 5
$$ 


\begin{tabular}{|c|c|c|c|c|c|}
\hline \multicolumn{6}{|c|}{ Controlled variables } \\
\hline Province &, $116^{*}$ &, $113^{*}$ &, $150^{*}$ &, $147^{* *}$ &, $142^{* *}$ \\
\hline Cluster &,- 006 &,- 003 &,- 027 &,- 025 &,- 026 \\
\hline Age & ,068 & ,060 & ,104 & ,096 & 101 \\
\hline \multicolumn{6}{|c|}{ Observe Variables } \\
\hline Gender & &,- 084 & &,- 086 &,- 087 \\
\hline Skill & & &, $202^{* * *}$ & &, $669^{* * *}$ \\
\hline Skill * Gender & & & &, $203^{* * *}$ &,$- 488^{* *}$ \\
\hline \multirow{2}{*}{$\begin{array}{l}\mathrm{R}^{2} \\
\square \mathrm{R}^{2}\end{array}$} & ,016 &, 023 & 054 &, 061 & ,082 \\
\hline & ,016 & ,007 &, $038^{* * *}$ &, $045^{* * *}$ &, $021^{* *}$ \\
\hline
\end{tabular}

Based on the table 5 , this study found that workers' skills $\left(\square=, 202^{* * *}\right)$ are significantly affect the readiness of AEC competition. They with a better skill have a better readiness to compete toward the competition at Asean Economic community (AEC). Workers' skill contribute 3.8\% to explain the their readiness to compete toward the competition at Asean Economic community (AEC). It shows that to compete toward AEC, Indonesian workers need to improve their skill in order to strengthen their readiness on AEC competition. The moderation result of the analysis shows that the skill of male $\left(\square=, 405^{* * *} ; \square \mathrm{R}^{2}=15,7 \%\right)$ and female $\left.\square \square=, 087 ; \square \mathrm{R}^{2}=, 7 \%\right)$ workers have significant different on their readiness to AEC competition( $\left.\square=-, 488^{* *} ; \square \mathrm{R}^{2}=2,1 \%\right)$. It indicates that the effect of skill on competition readiness for male is stronger compare to female (figure 1 ).

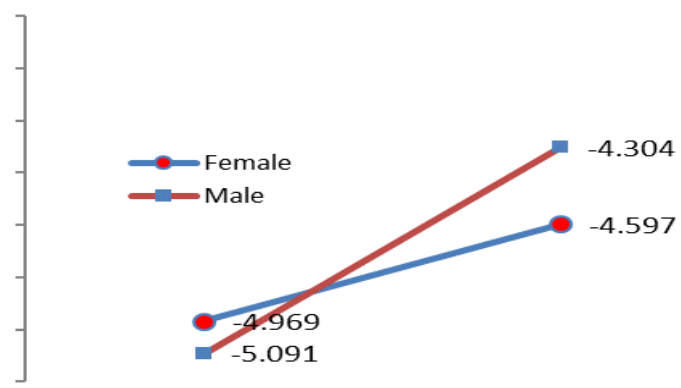

Figure 1 Moderation of gender on the effect of skill on competition readiness

Scholar found that specific skills discriminate against women that in turn endorse employers employe specific skills workers is likely to force occupational segregation by gender (Estevez-Abe, 2005). It is believed that females are different from males. They are more likely to pay more attentions to their family's needs. Hence they have different types of skills and its' implications. Accordingly specific or vocational skills required at work are biased against female. Others argue that female with better skill at work is seem to be unliked cause of their were self-centered that in turn female workers are perceived as less competent (Elsesser\& Lever,2011). Skill of male have a better effect on competition readiness rather than female because males are believed to have a better mental health, problem solving skill, competition skill, and adaptation at work rather than female (Garrett, 1989; Foschi, 1996; Nadler, Jazwinski, Lau, \& Miller, 1980; Dey, 2015; Rathod\& Kaji, 2015; Robert, 2016). Hence, males are likely to show the interaction of skill and their mental level promotes a better readiness to compate rather than their counterparts. Whereas to encouter the uncertainties in competitions, better adaptation ability of male may encourage

\section{Limitation and Future Research}

Notwithstanding these contributions, this study has its limitations. This study allows us to rule out Indonesian workers' skill to strengthen the evidence of readiness on AEC competition. However, it is open questions as to whether the results can be applied to different broader coverage of various sub conditions of competitions such as inter and intra new comer competition should become future attractive 
investigations. It might be expected to relate to AEC readiness of competition differently. An Additional longitudinal study of competition readiness of competitive advantages growth is plausible. It will likely able to explain the prediction of skill requirement on the future competitions. Measurement equivalence is now more than ever a general concern in organizational studies. Participants with different levels of occupation, and experimental versus control groups are highly recomended for further studies.

\section{References}

Allen, R., Burgess, S., \& Mayo, J. (2018), The teacher labour market, teacher turnover and disadvantaged schools: new evidence for England. Education Economics, 26(1), 4-23.

Anderson, J.C., and D.R., Gerbing, (1988), Structural equation modeling in practice: A Review and recommended two step approach, Psychological bulletin, 103, 411-423

Arellano-Yanguas, J., \& Bernal-Gómez, M. D. P. (2017) Partnerships for development in the extractive sector: protecting subterranean interests? Journal of Environmental Policy \& Planning, 19(3), 251-265.

Babushkina, G. D., Shumilinb, A. P., \&Chikurovb, A. I. (2011), Diagnostics and Correction of Pre-Competition Psychological Readiness of Judoists of Different Qualifications, Journal of Siberian Federal University. Humanities \& Social Sciences, 9(4), 1240-1250.

Bandura, A. (1977) Self-efficacy: toward a unifying theory of behavioral change. Psychological review, 84(2), 191.

Blix, M. Ã. (2018), The Effects of Digitalisation on Labour Market Polarisation and Tax Revenue, In CESifo Forum (pp. 09-14) Ifo Institute-Leibniz Institute for Economic Research at the University of Munich

Blumenstein, B., \&Orbach, I. (2016), Professional Coach: The Link between Science and Media. Sport Science Review, 25(1-2), 73-84.

Dey, P. (2015). Gender Gap in Education-An Indian Human Capital Formation Concern. Global Journal of Human-Social Science Research, 5(1)

Elsesser, K. M., \& Lever, J. (2011) Does gender bias against female leaders persist? Quantitative and qualitative data from a large-scale survey. Human Relations, 64(12), 1555-1578.

Estevez-Abe, M. (2005) Gender bias in skills and social policies: The varieties of capitalism perspective on sex segregation. Social Politics: International Studies in Gender, State \& Society, 12(2), 180-215.

Findlay, C., \&Pangestu, M. (2016), The Services Sector as a Driver of Change: Indonesia's Experience in the ASEAN Context. Bulletin of Indonesian Economic Studies, 52(1), 27-53.

Firmin, M. W., Lucius, J. E., \& Johnson, S. (2011) Student Perspectives of Competition: A Qualitative Analysis. American Journal of Business Education (AJBE), 2(2)

Fornell, C., \&Larcker, D. F. (1981), Structural equation models with unobservable variables and measurement error: Algebra and statistics. Journal of marketing research, 382-388

Foschi, M. (1996). Double standards in the evaluation of men and women. Social Psychology Quarterly, 237-254.

Fumarco, L., \& Rossi, G. (2018),The relative age effect on labour market outcomes-evidence from Italian football. European Sport Management Quarterly, 1-16.

Garrett, R. M. (1989). Problem-solving and Cognitive Style. Research in Science \& Technological Education, 7(1), 27-44.

Gist, M. E., \& Mitchell, T. R. (1992), Self-efficacy: A theoretical analysis of its determinants and malleability. Academy of Management review, 17(2), 183-211

Gitaharie, B. Y., \&Soelistianingsih, L. (2018), Indonesia's academic readiness in facing a freer flow of skilled labour in 2015 ASEAN Economic Community (AEC) implementation. Competition and Cooperation in Economics and Business.

Hawthorne, L. (2008, November), The growing global demand for students as skilled migrants. In Transatlantic Council on Migration's Second Plenary Meeting, New York

Hsu, M. H., Ju, T. L., Yen, C. H., \& Chang, C. M. (2007), Knowledge sharing behavior in virtual communities: The relationship between trust, self-efficacy, and outcome expectations. International journal of human-computer studies, 65(2), 153-169

Hunt, V., Layton, D., \& Prince, S. (2015) Diversity matters. McKinsey \& Company, 1, 15-29.

Imaroh, T. S. (2016) Entrepreneurship education as a strategy for improving the economical independence and competitive ability if society in ASEAN ECONOMIC COMMUNITY (AEC) ERA, International Journal of Organizational Innovation (Online), 9(2), 287. Chicago

Jones, L. (2015), Explaining the failure of the ASEAN economic community: the primacy of domestic political economy. The Pacific Review, 1-24.

Kis-Katos, K., Pieters, J., \& Sparrow, R. A. (2017) Globalization and Social Change: Gender-Specific Effects of Trade Liberalization in Indonesia.

Kraisuth, D., \&Panjakajornsak, V. (2018) Thai AEC Engineer Readiness: A Confirmatory Factor Analysis. SAGE Open, 8(1), 2158244017745346.

LeMaire, J., Short, S. E., Ross-Stewart, L., \& Short, M. (2007) The effect of uniform color on athletes' readiness for competition and perception of opponents' attributes. Journal of Sport \& Exercise Psychology, 29, 180-181. 
Llanto, G. M., Medalla, E. M., del Prado, F., Mantaring, M. C., Detros, K. C., Serafica, R. B., Ortiz, M., Kristina, P., Ortiz, D.A.P., Padronia, P.S \&Maddawin, A. B. (2015), Furthering the implementation of AEC blueprint measures (No. DP 2015-35)

LooiKee, H., Nicita, A., \&Olarreaga, M. (2009), Estimating trade restrictiveness indices. The Economic Journal, 119(534), 172199

Malik, P., Lenka, U., \&Sahoo, D. K. (2018) Proposing micro-macro HRM strategies to overcome challenges of workforce diversity and deviance in ASEAN. Journal of Management Development, (just-accepted), 00-00

McGee, J. E., Peterson, M., Mueller, S. L., \&Sequeira, J. M. (2009), Entrepreneurial self-efficacy: refining the measure. Entrepreneurship theory and Practice, 33(4), 965-988

Mishra, A. K., Rao, G., Monga, A., \&Vishwanath, B. (2016), Assessing Competitiveness in Emerging Asian Economies: Role of Governance and Infrastructure and Lessons for India. Emerging Economy Studies, 2394901515627732

Nadler, A., Jazwinski, C., Lau, S., \& Miller, A. (1980). The cold glow of success: Responses to social rejection as affected by attitude similarity between the rejected and chosen individuals. European Journal of Social Psychology, 10(3), 279289.

Nair, T. (2018) Climate Change and Food Insecurities: Destabilisers of ASEAN Centrality? In International Security in the Asia-Pacific (pp. 307-330) Palgrave Macmillan, Cham.

Nambiar, S. (2018) India's Connectivity with ASEAN: What Role for Northeast India?. In Mainstreaming the Northeast in India's Look and Act East Policy (pp. 131-158) Palgrave Macmillan, Singapore.

Ngin, P. C. (2005) Applying human capital management to model manpower readiness a conceptual framework (Doctoral dissertation, Monterey, California. Naval Postgraduate School)

Nunnally, J. C., \& Bernstein, I. H. (1994), Elements of statistical description and estimation, Psychometric Theory 3 Edition (Edited by: Nunnally JC, Bernstein IH)

Nur, M., Hadiwardoyo, S. P., Nahry, \&Nahdalina. (2017, June) Analysis on logistic company action toward the access restriction policy on freight vehicle. In AIP Conference Proceedings (Vol. 1855, No. 1, p. 040010) AIP Publishing.

Papademetriou, D. G., Sugiyarto, G., Mendoza, D. R., \&Salant, B. (2016), Achieving Skill Mobility in the ASEAN Economic Community: Challenges, Opportunities, and Policy Implications. Asian Development Bank.

Rana, P. B. (2017) Special Issue Of The Singapore Economic Review - Asean'S Long Term Economic Potential And Vision.

Rathod, J., \& Kaji, S. M. (2015). Mental Health of East and West Area People in Ahmedabad, The International Journal of Indian Psychology, 2(3), 4-9

Robert, S. A. (2016). Extending theorisations of the global teacher: care work, gender, and street-level policies. British Journal of Sociology of Education, 37(3), 445-464.

Siadari, D. L. Y., \& Arai, K. (2018) International Enforcement of ASEAN Competition Law. Journal of European Competition Law \& Practice.

Soesastro, H. (2003) An ASEAN Economic Community and ASEAN+ 3: How do they fit together?.

Soesastro, H. (2008), 'Implementing the ASEAN Economic Community (AEC) Blueprint', in Soesastro, H. (ed.), Deepening Economic Integration- The ASEAN Economic Community and Beyond-, ERIA Research Project Report 2007-1-2, Chiba: IDE-JETRO, pp.47-59.

Su, S., Sun, Y., Lei, C., Weng, M., \&Cai, Z. (2017) Reorienting paradoxical land use policies towards coherence: A selfadaptive ensemble learning geo-simulation of tea expansion under different scenarios in subtropical China. Land Use Policy, 67, 415-425.

Sukesi, K., Setyowati, E., Wahyuningtyas, A. S. H., \&Baladina, N. (2018) Changes in Socio-Economic and Cultural Behavior of Female Indonesian Migrant Workers. HABITAT, 28(3), 114-121.

Sumano, B. (2013) 'Explaining the liberalisation of professional migration in ASEAN', PhD thesis, School of Politics and International Relations, Queen Mary, University of London, London

Svetlicinii, A. (2017) Building regional competition policy in ASEAN: lessons from the European Competition Network. Asia Europe Journal, 15(3), 341-357.

Ushakov, D. S. (2016), Innovative Climate Development as a factor for National Econimy progress (The case of Thailand), Aktual'niProblemyEkonomiky= Actual Problems in Economics, (175), 94.

Vuong, Q. H., Napier, N. K., Vu, H. K., Nguyen, M. C., \& Tran, T. D. (2014) Measuring corporate innovation capacity: experience and implications from i2Metrix implementation in Vietnam. ASEAN Journal of Management \& Information, 1(1), 1-17.

Winarnita, M. S. (2018) Don't call me ibu: challenges of belonging for childless transnational Indonesian women. Global Networks, 18(1), 186-203.

Yue, C. S. (2011) Free Flow of Skilled Labor in the AEC. Singapore Institute of International Affairs, Singapore. 